\title{
A remarkable discovery of electrum on the island of Sylt, northern Germany, and its Scandinavian origin
}

\author{
Jochen Schlüter $^{1}$, Stephan Schuth ${ }^{2,5}$, Raúl O. C. Fonseca ${ }^{3,5}$, and Daniel Wendt ${ }^{4}$ \\ ${ }^{1}$ Mineralogisches Museum, Centrum für Naturkunde (CeNak), Universität Hamburg, \\ Grindelallee 48, 20146 Hamburg, Germany \\ ${ }^{2}$ Institut für Mineralogie, Leibniz Universität Hannover, Callinstraße 3, 30167 Hannover, Germany \\ ${ }^{3}$ Institut für Geowissenschaften, Rheinische Friedrich-Wilhelms-Universität Bonn, \\ Poppelsdorfer Schloss, 53115 Bonn, Germany \\ ${ }^{4}$ independent researcher: Hamburg, Germany \\ ${ }^{5}$ Institut für Geologie, Mineralogie und Geophysik, Ruhr-Universität Bochum, \\ Universitätsstraße 150, 44780 Bochum, Germany
}

Correspondence: Jochen Schlüter (jochen.schlueter@uni-hamburg.de)

Received: 26 April 2021 - Accepted: 20 May 2021 - Published: 14 July 2021

\begin{abstract}
An electrum-quartz pebble with a weight of $10.4 \mathrm{~g}$ was discovered in a cliff of Saalian glaciogenic sediments on the west coast of the German North Sea island of Sylt in 2012. It has a roundish water-worn appearance and consists of intergrown electrum and milky quartz. It is the largest known electrum find in Germany, and regarding its weight it also ranks amongst the largest gold finds discovered in Germany. We document and characterize this unusual discovery. Furthermore, an attempt is made to investigate its provenance. Therefore, reference samples of southern Scandinavian gold and electrum deposits and occurrences have been studied and compared to the Sylt find. The Au-Ag content determined by electron microprobe (EMP), trace element signature measured by laser ablation inductively coupled plasma mass spectrometry (LA-ICP-MS), and $\mathrm{Pb}$ isotope compositions by multi-collector ICP MS (MC-ICP-MS) suggest a southern Norwegian origin. The most probable source might be the Kongsberg ore district or an adjacent, yet undiscovered, mineralization in the Oslo region.

In general, Saalian glaciogenic sediments in Schleswig-Holstein (northern Germany) are dominated by rocks of Swedish provenance. Due to the intake of older Elsterian sediments by younger Saalian glaciers, southern Norwegian rocks are also not uncommon in Saalian sediments. A Saalian ice advance or a combination of Elsterian and Saalian ice advances might have provided a transport mechanism for an electrum sample from a south Norwegian mineralization to the island of Sylt.
\end{abstract}

\section{Introduction}

One of the authors (Daniel Wendt) noticed a conspicuous object, which later turned out to be an electrum-quartz pebble (Fig. 1) stuck in glaciogenic sediments at the top edge of a ca. $18 \mathrm{~m}$ high sea cliff on the west coast of the island of Sylt, Schleswig-Holstein, northern Germany, on 21 July 2012. The cliff is located between the villages of Wenningstedt and Kampen and is called "Rotes Kliff” (Red Cliff). The electrum was found embedded in till and exposed by a small erosion channel which drains surface water from the cliff (Fig. 2).
Subsequent intense efforts with metal detectors to find further samples with precious metal content in November of the same year were unsuccessful. Moreover, the Rotes Kliff has been designated as a nature reserve since 1979, registered under CDDA-Code 81561. Because it is a strongly protected nature sanctuary, any kind of invasive activities at the cliff are prohibited, which ruled out further sampling of the glacial till to search for additional electrum or gold particles.

The electrum-quartz pebble with a weight of $10.4 \mathrm{~g}$ has a roundish water-worn appearance and consists of intergrown 


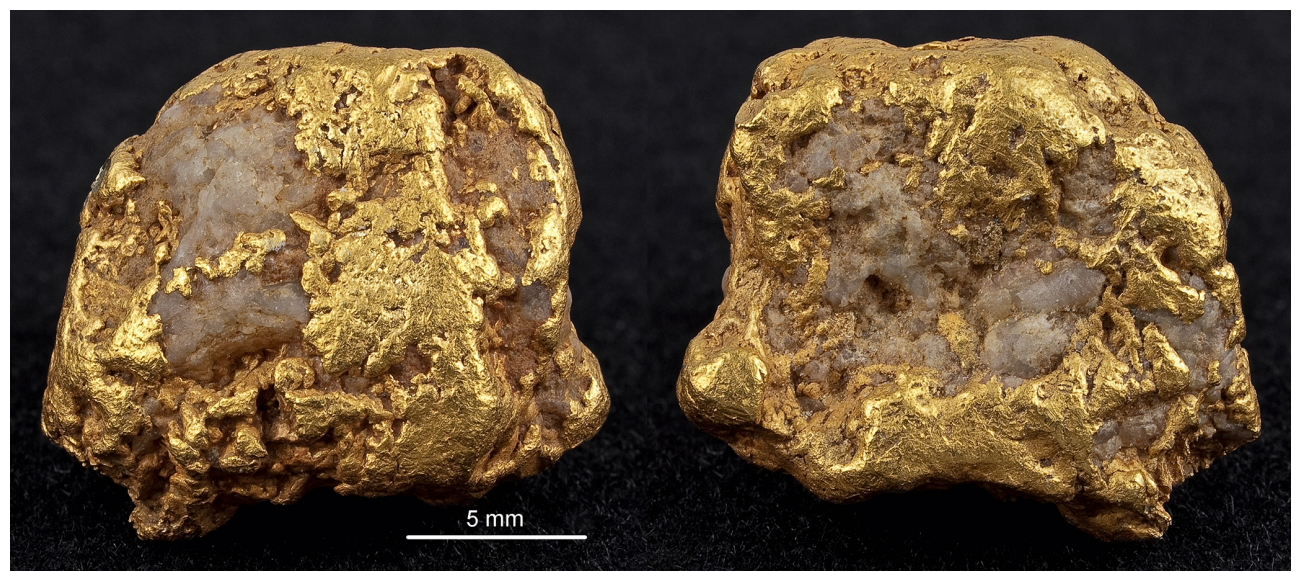

Figure 1. Electrum-quartz pebble with a weight of $10.4 \mathrm{~g}$ (front and back) found in till on the island of Sylt in 2012 (Photo: KarlChristian Lyncker). The electrum has the appearance of gold as its surface is depleted of silver.

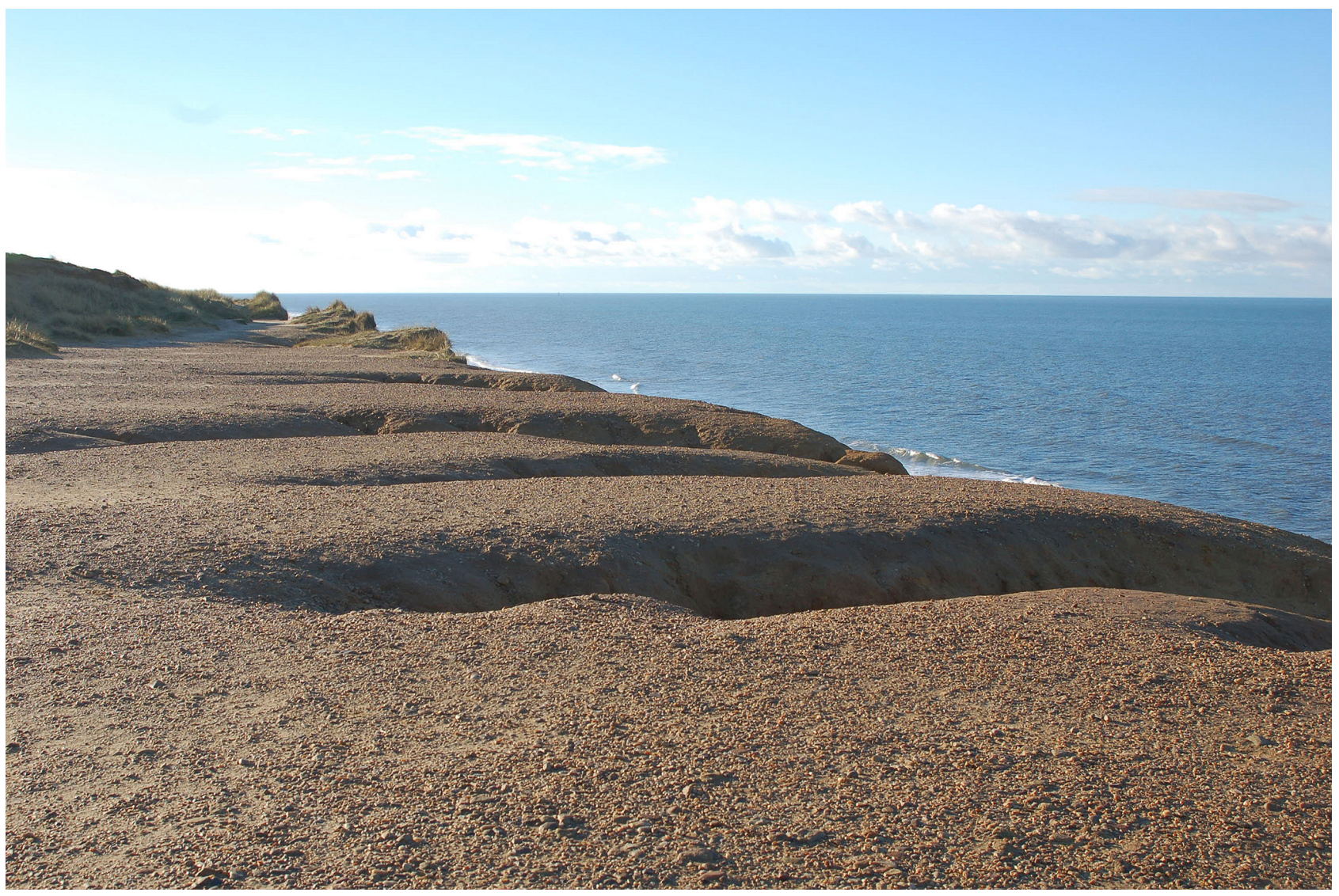

Figure 2. Erosion channels in Saalian till on the cliff edge, Rotes Kliff, Sylt, Germany. The picture was taken in November 2012, and the cliff has further receded since then (Photo: Jochen Schlüter; width of the foreground: $2.5 \mathrm{~m}$ ).

electrum crystals with milky quartz. The find consists of about $60 \mathrm{vol} . \%$ metal and $40 \mathrm{vol} . \%$ quartz. The outer rim of the metal is depleted in silver, a common feature of alluvial gold nuggets (e.g. Kerr et al., 2017; Stewart et al., 2017).
Thus, it shows the typical yellow colour of gold, hiding its real nature.

Schleswig-Holstein has no primary gold occurrences, but traces of gold are known from sand and gravel pits, as well as from beach placers. Several enterprises in Schleswig- 
Holstein exploit fluvio-glacial sand and gravel deposits. The gold within these sediments originates from the Scandinavian provenance regions of the glaciers (Lierl and Jans, 1990; Lierl and Sänger von Oepen, 1993). Gold can turn up in the heavy mineral and metal separators. Generally speaking, tiny nuggets up to $0.1 \mathrm{~mm}$ in diameter are found in those heavy mineral concentrates, but few grains can reach $1 \mathrm{~mm}$ (Lierl and Jans, 1990; Lierl and Sänger von Oepen, 1993). In Germany, natural gold or electrum finds with a weight of several grams are quite rare. The discovery of two gold nuggets with weights of 64.6 and $33 \mathrm{~g}$ in 1826 and 1828, respectively, in the Hunsrück area, Rhineland-Palatinate, as well as several finds of quartz pebbles with native gold between 1800 and the beginning of the 20th century, have been reported (Schade, 2014), but the whereabouts of these finds are unknown. The largest natural gold find that still remains in Germany is a gold nugget with a weight of about $10.2 \mathrm{~g}$ found in the 16th century in the river Schwarza, Thuringian Forest. A gold nugget with a weight of $9.64 \mathrm{~g}$ was also discovered in the Schwarza valley about 450 years later in 2004 (Schade, 2014). Considering the above-mentioned finds in Germany, the electrum-quartz pebble from Sylt with its weight of $10.4 \mathrm{~g}$ ranks among the largest "gold" finds in Germany.

The aim of our study is threefold. We focused on documenting this find, characterizing its provenance, and identifying a possible transportation mechanism from its place of origin to its find location in northern Germany. If the Sylt electrum-quartz pebble originates from a known gold mineralization or a deposit with noble metal content, our investigations might provide a link between this source and the Sylt find. However, if the source mineralization has been totally eroded by glaciers, or is not exposed at the surface or is underwater and thus undiscovered, it might still be possible to name at least a region for a potential provenance of our find. For an attempt to link the Sylt find with known gold occurrences, it would be desirable to analyse several representative samples of each gold and electrum occurrence known in Scandinavia to take the chemical variability within the deposits into account. Unfortunately, samples are not available from each of the numerous known electrum and gold deposits in Scandinavia, and trace element analyses of native gold from those occurrences that are accessible are still rare in the literature.

The authors are well aware of the problem that the available reference samples (Table 1) are not sufficient for a reliable determination of the provenance of the electrum discovery. However, the find is so unusual in terms of find location and size that at least an approximation of the questions is attempted here.

\section{Geological setting and provenance envelope}

Germany's most northern state, Schleswig-Holstein, is almost entirely covered by Quaternary sediments. Locally,

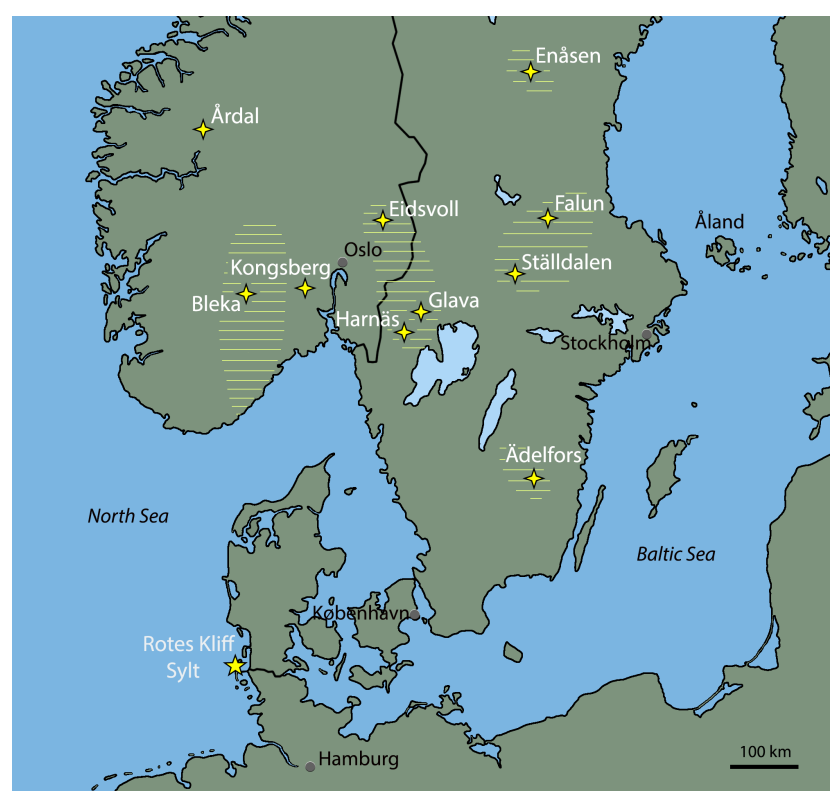

Figure 3. Site of the Sylt electrum find (yellow star) with gold-bearing areas and gold deposits in southwestern Fennoscandia based on Sundblad and Ihlen (1995) (Map courtesy of Matthias Bräunlich).

older rocks are exposed because ascending Permian salt diapirs have uplifted these older units to the surface. Such salt domes are a common geological feature in northern Germany (e.g. Trusheim, 1960). The North Friesian island of Sylt is the northernmost island of Germany situated off SchleswigHolstein's North Sea coast (Fig. 3). Its Neogene bedrock is mainly covered by Elsterian and Saalian glacial sediments which are in turn covered and surrounded by younger sand and gravel deposits or marshlands (Dietz and Heck, 1952). The $4.5 \mathrm{~km}$ long Rotes Kliff, between Kampen and Wenningstedt, exposes two layers of subglacial till which are separated by a sand layer. Both till layers are deposits of the Drenthe stage (at ca. 160-150 ka, Marine Isotope Stage 6; e.g. Hughes and Gibbard, 2018) of the Saalian glaciation (Felix-Henningsen and Urban, 1982). The Sylt electrumquartz pebble was found embedded in till of the upper Drenthe substage about $6 \mathrm{~cm}$ below the current cliff surface.

To evaluate a possible provenance for this electrum find, the provenance envelope of the Saalian glaciers requires consideration, which is a hypothetical envelope widening up-ice from the sampling site defined by the ice-flow movement and the lateral extent of all potential bedrock sources (Stea and Pe-Piper, 1999). It is an area or region from where debris was glacially transported in a cumulative effect of varying ice-flow directions of a glaciation (Plouffe et al., 2011). In addition to material from this source region, the final glacial deposit can include material from earlier transport events, for example, if a till was derived from older glacial sediments. In northern Germany multiple cycles of ice advance and melt- 
Table 1. Gold and electrum reference samples used in this study (nos. 1-2, 4-10) and references of data used for comparison.

\begin{tabular}{|c|c|c|c|c|c|c|}
\hline No. & Mine & Locality & $\mathrm{Au} / \mathrm{Ag}$ & Trace elements $^{\mathrm{b}}$ & $\mathrm{Pb}$ isotopes & Sample source \\
\hline 1 & Kongsberg A & $\begin{array}{l}\text { Kongsberg silver min- } \\
\text { ing district, Svene, } \\
\text { Flesberg, Buskerud, } \\
\text { Norway }\end{array}$ & This study $^{\mathrm{a}}$ & This study & $\begin{array}{l}\text { This study }{ }^{\mathrm{c}} \text {; Bjørlykke } \\
\text { et al. (1990) }\end{array}$ & $\begin{array}{l}\text { Mineralogisches } \mathrm{Mu}- \\
\text { seum Hamburg }\end{array}$ \\
\hline 2 & Kongsberg B & $\begin{array}{l}\text { Kongsberg silver min- } \\
\text { ing district, Svene, } \\
\text { Flesberg, Buskerud, } \\
\text { Norway }\end{array}$ & This study $^{\mathrm{a}}$ & This study & Bjørlykke et al. (1990) & $\begin{array}{l}\text { Museum für } \\
\text { Naturkunde Berlin }\end{array}$ \\
\hline 3 & Kongsberg & $\begin{array}{l}\text { Kongsberg silver min- } \\
\text { ing district, Svene, } \\
\text { Flesberg, Buskerud, } \\
\text { Norway }\end{array}$ & $\begin{array}{l}\text { Unpublished, } \\
\text { Fred Steinar Nordrum, } \\
\text { personal communica- } \\
\text { tion (2016) }\end{array}$ & & & \\
\hline 4 & Bleka & $\begin{array}{l}\text { Bleka gold mine (Bleka } \\
\text { mine), Bleka, Svartdal, } \\
\text { Seljord, Telemark, Nor- } \\
\text { way }\end{array}$ & This study* & This study & & Bergakademie Freiberg \\
\hline 5 & Eidsvoll & $\begin{array}{l}\text { Eidsvoll gold mines, } \\
\text { Eidsvoll (Eidsvold), } \\
\text { Akershus, Norway }\end{array}$ & This study* & This study & Ihlen et al. (1995) & $\begin{array}{l}\text { Museum für } \\
\text { Naturkunde Berlin }\end{array}$ \\
\hline 6 & Harnäs & $\begin{array}{l}\text { Harnäs mine, Sillerud, } \\
\text { Årjäng, Värmland, } \\
\text { Sweden }\end{array}$ & $\begin{array}{l}\text { This study }{ }^{\mathrm{a}} \text {; Alm and } \\
\text { Sundblad (1994) }\end{array}$ & This study & $\begin{array}{l}\text { This study }{ }^{\mathrm{c}} \text {; Alm and } \\
\text { Sundblad (1994) }\end{array}$ & $\begin{array}{l}\text { Geological Survey of } \\
\text { Sweden, Uppsala }\end{array}$ \\
\hline 7 & Ädelfors & $\begin{array}{l}\text { Ädelfors, Alseda, Vet- } \\
\text { landa, Småland, Swe- } \\
\text { den }\end{array}$ & This study* & This study & $\begin{array}{l}\text { Romer and Wright } \\
(1993)\end{array}$ & $\begin{array}{l}\text { Geological Survey of } \\
\text { Sweden, Uppsala }\end{array}$ \\
\hline 8 & Falun & $\begin{array}{l}\text { Falun mine, Falun, } \\
\text { Dalarna, Sweden }\end{array}$ & This study ${ }^{\mathrm{a}}$ & This study & $\begin{array}{l}\text { Romer and Wright } \\
(1993)\end{array}$ & $\begin{array}{l}\text { Geological Survey of } \\
\text { Sweden, Uppsala }\end{array}$ \\
\hline 9 & Årdal & $\begin{array}{l}\text { Årdal copper mines, } \\
\text { Årdal, Sogn og Fjor- } \\
\text { dane, Norway }\end{array}$ & This study ${ }^{\mathrm{a}}$ & This study & & $\begin{array}{l}\text { Museum für } \\
\text { Naturkunde Berlin }\end{array}$ \\
\hline 10 & Ställdalen & $\begin{array}{l}\text { Ställdalen placer, } \\
\text { Ställdalen, Ljusnars- } \\
\text { berg/Kopparberg, } \\
\text { Västmanland, Sweden }\end{array}$ & This study* & This study & & $\begin{array}{l}\text { Mineralogisches } \\
\text { seum Hamburg }\end{array}$ \\
\hline
\end{tabular}

${ }^{a}$ Gold and silver analyses employing EMP, Hamburg; ${ }^{b}$ trace element analyses in gold employing LA-ICP-MS, Bonn and Hannover; ${ }^{\mathrm{c}}$ Pb isotope analyses in gold employing MC-ICP-MS, Hannover.

ing occurred during all glaciation events, with changing directions of ice movements during advancement of the ice masses. In detail, glaciers of all three glaciations moved first from the north to the south, subsequently from the northeast to the southwest, and finally from east to west (e.g. Stephan, 2003; Lang et al., 2018). The provenance of those sections of the Saalian inland ice sheet, which reached SchleswigHolstein, dominantly ranges from southeast Sweden (east of the Protogine Shear Zone; Fig. 4) to the Åland islands and westernmost Finland. However, rocks from more westerly regions also occur in these glacial sediments. In the Drenthe till of the Rotes Kliff but also in the Drenthe till of the Steenodde cliff on the small adjacent Frisian island of Amrum (south of Sylt) or in the Emmerlev Klev (a sea cliff on the Danish coast $22 \mathrm{~km}$ east-northeast of the Rotes Kliff), rocks can be found which have their origin in southeastern Norway or in southwestern Sweden (i.e. west of the Protogine Shear Zone) (Roland Vinx, personal communication, 2020; Stephan, 2020). Significant amounts of rocks from southeastern Norway and southwestern Sweden were dislocated by Elsterian glaciers which covered northern Germany in a north-south direction as far as to the margins of the central German uplands (Stackebrandt et al., 2001; Stephan, 2003; Ehlers et al., 2011; Lang et al., 2018). Consequently, Saalian glaciers did not only transport erratic rocks directly from their outcrop occurrences to Schleswig-Holstein but also redistributed erratic rocks which were picked up en route from older Elsterian deposits. Taking the known rock inventory of Saalian deposits in Schleswig-Holstein into consideration, a southern Scandinavian provenance envelope can be drawn 


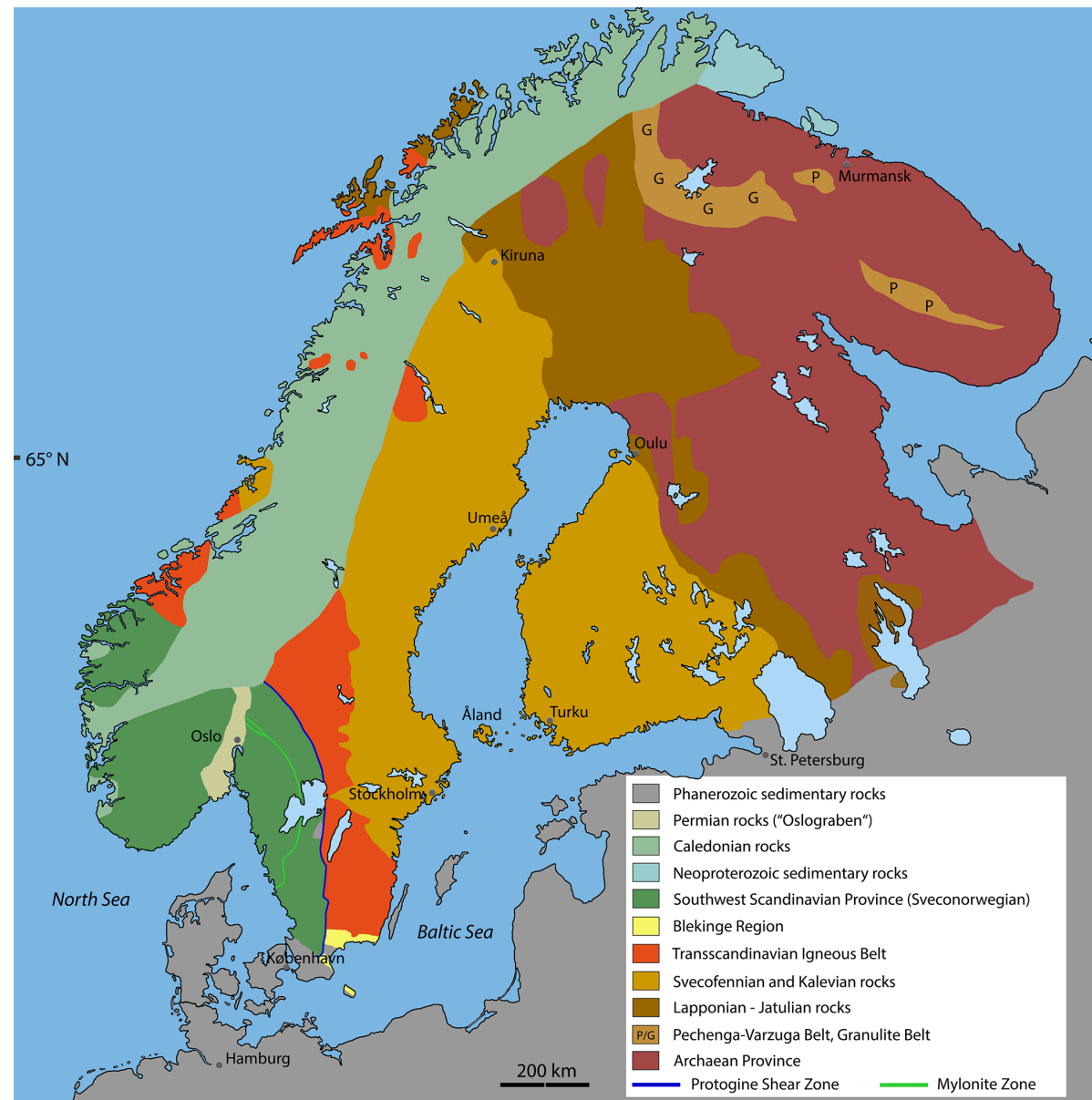

Figure 4. Geotectonic provinces of the Fennoscandian Shield (based on Gaál and Gorbatschev, 1987; map courtesy of Matthias Bräunlich).

which confines the original source of the Sylt electrum to a corridor encompassing an area from mid-Norway to western Finland with a northern limit around 64 to $65^{\circ} \mathrm{N}$ because erratic rocks from higher latitudes are virtually unknown in northern Germany.

Due to its water-worn appearance, roundness, and the depletion of silver on its surface, the Sylt electrum-quartz pebble must have been transported by ancient rivers or glacial meltwater in addition to its glacial transport (for details of nuggets see also, for example, Craw et al., 2017; Kerr et al., 2017; Stewart et al., 2017; Rea et al., 2019).

\section{Gold deposits in southern Scandinavia}

Scandinavia hosts hundreds of gold deposits of a variety of ages and genetic styles which are found in rocks linked to the Paleoproterozoic Svecokarelian orogeny or the Neoproterozoic Sveconorwegian orogeny (e.g. Sundblad, 2003). Scandinavia's bedrock is part of the Precambrian Fennoscandian or Baltic Shield. From its oldest northeastern parts, the rocks of the shield are getting progressively younger towards the southwest as younger orogenic events accreted additional geological units to the Archean nucleus. In this context the Fennoscandian Shield can be divided into different crustal domains (Fig. 4): the Archean, the Proterozoic Svecofennian including the Transscandinavian Igneous Belt, and the southwestern Scandinavian (or Gothian) domain which is characterized by the Sveconorwegian orogeny (e.g. Sundblad, 2003). The western margins of the Baltic Shield are overlain by a series of nappes which were thrusted onto it during the early Paleozoic Caledonian orogeny. Later periods of crustal extension, which led to rifting and graben formation, are documented, amongst others, by the Permian Oslo paleo-rift in southern Norway (for example, Ihlen, 1986a).

As described above, the ice movements of the relevant glaciation events (Elsterian and Saalian) define a provenance envelope for the glacial sediments deposited on the island of Sylt. This envelope extends mostly over rocks and deposits of the Sveconorwegian domain and the southern part of the Svecofennian domain with the Transscandinavian Igneous Belt.

Several gold deposits or mineralizations with gold content are known from those regions. In addition, diverse Quaternary gold placer occurrences are known from Norway (Of- 
ten, 1995) and Sweden (Ställdalen, collection of the Mineralogical Museum Hamburg). Sundblad and Ihlen (1995) define several districts with gold-bearing areas and gold deposits in the considered provenance envelope: the Enåsen and Bergslagen (Falun) and Ädelfors districts in the Svecofennian domain and the Vetlanda group, as well as the MjøsaVänern (Harnäs, Glava, Eidsvoll) and Telemark (Bleka) districts in the Sveconorwegian domain (Figs. 3 and 4). The Enåsen district hosts the Enåsen gold deposit within highgrade metamorphic gneisses of Paleoproterozoic age. Its economic mineralization consists of disseminated chalcopyrite and gold in a topaz-bearing quartz-sillimanite gneiss (Hallberg, 1994, 1995). Moreover, several massive sulfide deposits with significant gold content are known from the Bergslagen district, but gold production has never played a major role in these mines. Only the Falun mine showed increased gold production due to an Au-Se-rich zone which was formed from a hydrothermal system that post-dated the massive sulfide ore deposition. The gold was found in a quartz-rich and sulfide-poor ore with various rare $\mathrm{Bi}-\mathrm{Pb}-\mathrm{Se}-$ S compounds (Sundblad, 2003). The Ställdalen placer gold is genetically linked to this district.

The Ädelfors district is named after the Ädelfors deposit, the first gold mine in Swedish history. The ore at Ädelfors consists of $\mathrm{Au}-\mathrm{Cu}-\mathrm{Zn}$-bearing quartz veins with Co-enriched pyrite in mafic metavolcanic rocks of the Vetlanda group, which was originally seen as part of the Svecofennian domain but is considered now to be a younger unit (Lindström et al., 2000). Gold is rarely seen macroscopically but can be identified microscopically in almost all sulfide-bearing samples. The size of the gold grains varies between 5 and $600 \mu \mathrm{m}$, but millimetre-sized grains of native gold are known. Gold is also found as isolated grains within a quartz matrix (Bergman, 1986; Ihlen et al., 1995; Sundblad, 2003). Furthermore, three gold occurrences, Harnäs, Glava, and Eidsvoll, are situated in the Mjøsa-Vänern district. Epigenetic hydrothermal gold quartz veins were discovered in the Harnäs area, southwestern Sweden, in the late 1980s. They are located in Mesoproterozoic granitoid gneisses of the Sveconorwegian domain in the Fennoscandian Shield. Gold with Ag contents up to 20 wt. \% (i.e. classified as electrum) occurs here in close association with pyrite-rich portions of the quartz veins, usually filling fractures and cavities in pyrite but occasionally as inclusions in galena and aikinite or in the gangue quartz (Alm and Sundblad, 1994; Alm et al., 1995, 2003; Sundblad, 2003).

The Glava-South $\mathrm{Cu}-\mathrm{Au}-\mathrm{Ag}$ vein deposit is also located in gneissic host rocks, only about $40 \mathrm{~km}$ northeast of the Harnäs mine. Its centimetre-wide open fractures are filled with bornite, chlorite, and minor quartz with minor amounts of common sulfides and electrum and a large variety of tellurides and subordinate selenides. Electrum occurs only as micrometre-sized grains, with a range of compositions between 73.2 wt. \%-86.0 wt. \% Au and 11.3 wt. \%-26.7 wt. \% Ag (Oen and Kieft, 1984; Sundblad, 2003).
In the Eidsvoll mining area, southeastern Norway, gold was associated with quartz veins. Chalcopyrite is the dominant sulfide with pyrite, galena, and accessory Bi-bearing phases as important ore constituents. Native $\mathrm{Au}$, which rarely exceeds $100 \mu \mathrm{m}$, occurs locally as inclusions in pyrite but is in most cases found intergrown with the late-stage minerals, especially Cu sulfides (Ihlen, 1995; Sundblad, 2003).

The most westerly ore district within the glacial provenance envelope considered here is the Telemark district, southern Norway. Gold-bearing ankerite-tourmaline-quartz veins are found, amongst others, at the Bleka gold field hosted in a large metamorphosed gabbroic sill complex of the Middle Proterozoic Telemark supracrustal suite. Petersen and Jensen (1995) describe "visible" gold with bismuthinite, chalcopyrite, and pyrite from the Bleka veins. Situated west of the considered glacial provenance envelope but added here for the sake of completeness is Au from the Årdal copper mines which also features an elevated silver content.

Not regarded as a gold deposit but known for electrum occurrences, and for this reason added in this study, is the Kongsberg silver district located about $60 \mathrm{~km}$ east of the Bleka mine and about $80 \mathrm{~km}$ west of Oslo (Ihlen, 1986b; Ihlen and Nordrum,1986). The Kongsberg area is well known for its occurrences of numerous Permian hydrothermal vein deposits including native silver or base metals. Kullerud (2020) describes electrum samples from Kongsberg, which are always found within discrete quartz veins distinct to the dominant calcite silver veins of Kongsberg, and shows a sample of the Beständige Liebe mine with centimetre-sized electrum batches.

\section{Materials and methods}

Gold reference samples (Table 1) were kindly provided by the Geological Survey of Sweden, Uppsala, Sweden (Harnäs, No. 20020103; Falun, No. 9/238; Ädelfors, No. 9/236), from the Museum für Naturkunde, Berlin, Germany (Eidsvoll, No. 2007-04763; Kongsberg, No. 2007-04756; Årdal, 200704750), the Technische Universität Bergakademie Freiberg (Freiberg University of Mining and Technology), Germany (Bleka), and the Mineralogisches Museum Hamburg, Centrum für Naturkunde (CeNak; Mineralogical Museum Hamburg, Centre of Natural History), Hamburg, Germany (Kongsberg; Ställdalen).

The gold and silver contents - except six analyses provided by Fred Steinar Nordrum - were determined by quantitative electron microprobe (EMP) analysis. It was carried out using a Cameca electron microprobe (CAMECA SX 100) at the Mineralogical Institute, University of Hamburg, Germany, operating in the wavelength-dispersion mode, with an accelerating voltage of $20 \mathrm{kV}$, a specimen current of $20 \mathrm{nA}$, and a beam diameter of approximately $1 \mu \mathrm{m}$. The standards used were $\mathrm{Au} 100 \%(\mathrm{Au} L \alpha)$ and $\mathrm{Ag} 100 \%(\mathrm{Ag} L \alpha)$. 
Trace elements in our gold samples were analysed by laser ablation inductively coupled plasma mass spectrometry (LA-ICP-MS) at the Institute of Geosciences, Rheinische Friedrich-Wilhelms-Universität Bonn (University of Bonn), Germany, using a M50-E Resonetics $193 \mathrm{~nm}$ excimer laser coupled to a Thermo Fisher X-Series II quadrupole ICPMS. The following nuclides were monitored: ${ }^{53} \mathrm{Cr},{ }^{55} \mathrm{Mn}$, ${ }^{57} \mathrm{Fe},{ }^{59} \mathrm{Co},{ }^{60} \mathrm{Ni},{ }^{62} \mathrm{Ni},{ }^{65} \mathrm{Cu},{ }^{66} \mathrm{Zn},{ }^{68} \mathrm{Zn},{ }^{75} \mathrm{As},{ }^{78} \mathrm{Se},{ }^{105} \mathrm{Pd}$, ${ }^{107} \mathrm{Ag},{ }^{108} \mathrm{Pd},{ }^{109} \mathrm{Ag},{ }^{111} \mathrm{Cd},{ }^{118} \mathrm{Sn},{ }^{119} \mathrm{Sn},{ }^{120} \mathrm{Sn},{ }^{121} \mathrm{Sb}$, ${ }^{123} \mathrm{Sb},{ }^{125} \mathrm{Te},{ }^{195} \mathrm{Pt},{ }^{208} \mathrm{~Pb}$, and ${ }^{209} \mathrm{Bi}$. All count rates were normalized to the internal standards ${ }^{197} \mathrm{Au}$ or ${ }^{57} \mathrm{Fe}$.

Trace elements (analysing the nuclides ${ }^{53} \mathrm{Cr},{ }^{55} \mathrm{Mn},{ }^{57} \mathrm{Fe}$, ${ }^{59} \mathrm{Co},{ }^{61} \mathrm{Ni},{ }^{65} \mathrm{Cu},{ }^{66} \mathrm{Zn},{ }^{68} \mathrm{Zn},{ }^{75} \mathrm{As},{ }^{77} \mathrm{Se},{ }^{108} \mathrm{Pd},{ }^{109} \mathrm{Ag}$, ${ }^{111} \mathrm{Cd},{ }^{117} \mathrm{Sn},{ }^{119} \mathrm{Sn},{ }^{121} \mathrm{Sb},{ }^{125} \mathrm{Te},{ }^{195} \mathrm{Pt},{ }^{197} \mathrm{Au},{ }^{208} \mathrm{~Pb}$, and ${ }^{209} \mathrm{Bi}$ ) in the Harnäs gold sample were analysed by LAICP-MS at the Institute of Mineralogy, Leibniz University Hannover, Germany. A Spectra-Physics Solstice femtosecond UV laser system coupled to a Thermo Scientific Element XR fast-scanning sector-field ICP-MS was employed. All count rates were normalized to $100 \%$ with the PGE-A reference material being analysed as an unknown sample.

Lead isotopes of the Sylt electrum and samples of Kongsberg A (electrum) and Harnäs (gold) were determined at the Institute of Mineralogy, Leibniz University Hannover, Germany (Table 1). The analyses were performed with a Thermo Scientific Neptune Plus multi-collector inductively coupled plasma mass spectrometer (MC-ICP-MS). The Tl isotope standard NBS-997 was added as a monitor for instrumental mass fractionation prior to analyses (see Schuth et al., 2011, for details). All $\mathrm{Pb}$ isotope data are normalized to the NBS981 reference value.

Analytical details are provided in the Supplement.

\section{Geochemical investigations}

To evaluate the provenance of the Sylt electrum find, as many gold and electrum samples as possible from mines of the above-described ore districts and adjacent areas were requested and provided from different collections and institutions (Table 1) for comparison. With the exception of Enåsen and Glava-South, at least one reference sample could be achieved from each of the ore districts. The samples originate from prominent deposits where visible native gold or electrum is found or was found in the past.

\section{Results and discussion}

\subsection{Au/ Ag ratios}

The comparison of the available reference samples (Table 2) with the Sylt electrum reveals three broad groups based on Au and Ag content (Fig. 5):

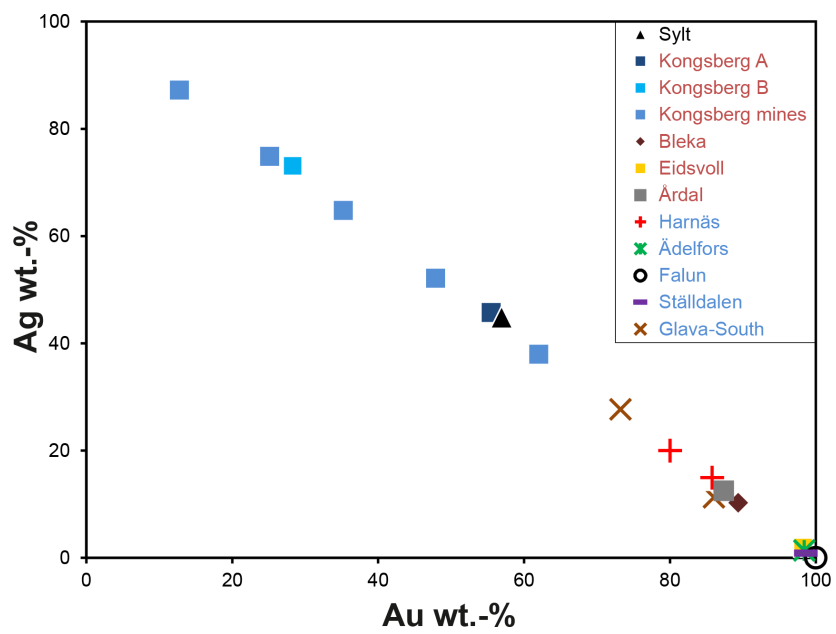

Figure 5. Gold and silver contents of the Sylt electrum find, as well as of gold and electrum reference samples from southern Scandinavia (Tables 1 and 2). Red labelling: Norway; blue labelling: Sweden.

1. Ag-poor gold $(<10 \mathrm{wt} . \% \mathrm{Ag})$ dominates most of our samples from Swedish mines and the Eidsvoll mine in southeastern Norway.

2. Gold from our samples of the Harnäs mine in the MjøsaVänern district, the Bleka mine in the Telemark district, and gold from the Årdal copper mines show Ag contents around 10 wt. \% to 16 wt. \%. Gold with Ag contents up to $20 \mathrm{wt}$. \% was mentioned by Alm et al. (1995) from the Harnäs mine. Electrum grains in the GlavaSouth deposit show Ag contents between $11.3 \mathrm{wt} . \%$ and 26.7 wt. \% (Oen and Kieft, 1984).

3. Electrum samples of the Kongsberg ore district are characterized instead by $\mathrm{Ag}$-rich gold to $\mathrm{Au}$-rich silver (i.e. $\mathrm{Ag}$ ranges from ca. $38 \mathrm{wt} \%$ to $87 \mathrm{wt} \%$ and $\mathrm{Au}$ from ca. 13 wt. $\%$ to 62 wt. $\%$; see Table 2).

The Sylt electrum has an $\mathrm{Au} / \mathrm{Ag}$ ratio of 56/44 wt. \%. It exhibits a higher silver content than all other reference samples from southern Scandinavian gold occurrences, yet it plots within the range of Kongsberg electrum samples. Only the rim of the Sylt electrum find is depleted in Ag with a content of only $3.6 \mathrm{wt}$. \% Ag on average, but this is likely due to a secondary process (i.e. fluvial transport) (Kerr et al., 2017; Stewart et al., 2017). Nevertheless, Au/Ag ratios alone are insufficient to accurately identify the provenance of the Sylt electrum find, and thus more information is needed.

\subsection{Trace element signatures}

A review of studies on the trace element composition of native gold from various deposits worldwide shows that gold mineralizations display large variations in their trace element contents. Each deposit has its own suite of detectable ele- 
Table 2. EMP analyses of gold and electrum samples from Sylt, Kongsberg, and other southern Scandinavian gold occurrences (this study) complemented by published and unpublished data ( ${ }^{\mathrm{a}}$ Alm and Sundblad, 1994; ${ }^{\mathrm{b}}$ Oen and Kieft, 1984; ${ }^{\mathrm{c}}$ unpublished data, Fred Steinar Nordrum, Kongsberg, personal communication).

\begin{tabular}{|c|c|c|c|}
\hline & $\mathrm{Au}$ (wt. \%) & Ag (wt. \%) & Total (wt. \%) \\
\hline Sylt, core & 56.9 & 44.9 & 101.8 \\
\hline Sylt, rim & 96.4 & 3.6 & 100.0 \\
\hline Årdal & 87.4 & 12.5 & 99.9 \\
\hline Ädelfors & 98.4 & 1.4 & 99.8 \\
\hline Bleka & 89.3 & 10.3 & 99.6 \\
\hline Boliden & 98.5 & 1.3 & 99.8 \\
\hline Eidsvoll & 98.2 & 1.9 & 100.1 \\
\hline Falun & 100.1 & - & 100.1 \\
\hline Harnäs & 85.8 & 15.0 & 100.8 \\
\hline Harnäs $^{\mathrm{a}}$ & $\min .80 .0$ & $\max .20 .0$ & \\
\hline Glava-South $^{\mathrm{b}}$ & $\max .86 .0$ & $\min .11 .3$ & \\
\hline Glava-South $^{\mathrm{b}}$ & $\min .73 .2$ & $\max .26 .7$ & \\
\hline Ställdalen & 98.7 & 0.8 & 99.5 \\
\hline Kongsberg A & 55.5 & 45.8 & 101.3 \\
\hline Kongsberg B & 28.3 & 73.1 & 101.4 \\
\hline Kongsberg, Beständige Liebe mine ${ }^{c}$ & $62.0-62.3$ & $38.0-37.7$ & \\
\hline Kongsberg, Skara mine ${ }^{c}$ & $23.7-26.9$ & $76.3-73.1$ & \\
\hline Kongsberg, Louise Augusta mine ${ }^{c}$ & $47.5-48.2$ & $52.5-51.8$ & \\
\hline Kongsberg, Fräulein Christiane mine ${ }^{\mathrm{c}}$ & $12.5-13.0$ & $87.5-87.0$ & \\
\hline Kongsberg, Neue Segen Gottes mine, core ${ }^{c}$ & 35.2 & 64.8 & \\
\hline Kongsberg, Neue Segen Gottes mine, rim $^{\mathrm{c}}$ & 25.1 & 74.9 & \\
\hline
\end{tabular}

ments, and absolute concentrations of detected elements can vary considerably between deposits. Gold from individual deposits appears to have a distinct trace element signature, and alluvial gold can retain the trace element signature of its bedrock (e.g. McInnes et al., 2008; Chapman et al., 2014; Chapman and Mortensen, 2016; Chapman et al., 2017, and references therein). Therefore, in this study the Sylt electrum find and gold reference samples from southern Scandinavian gold occurrences were analysed with LA-ICP-MS for their trace element signature for comparison (Fig. 6). As far as we are aware, there are no LA-ICP-MS data of trace element concentrations obtained from native gold samples of southern Scandinavian gold occurrences available in the literature. Thus, the following considerations are only based on the data obtained in this study.

The placer gold from Ställdalen (high Cd, Sn and Pt, low Ag when compared with the Sylt electrum) and the gold from the Falun mine (high $\mathrm{Cu}$, low $\mathrm{Pb}$, no $\mathrm{Ag}$ in comparison to the sample from Sylt), both in the Bergslagen district, show no similarities with the electrum from Sylt. Taking only the gold references with significant silver content (Harnäs, Bleka, Årdal) and the two prominent gold mines in southern Scandinavia, Eidsvoll and Ädelfors, into closer consideration (Fig. 6), the trace element signatures of the gold samples still show noticeable differences in their average element concentrations. Compared with the electrum find from Sylt (Table 3), the Eidsvoll gold sample shows significantly higher levels of $\mathrm{Cu}, \mathrm{Pd}$, and $\mathrm{Bi}$. The Bleka gold is also com-

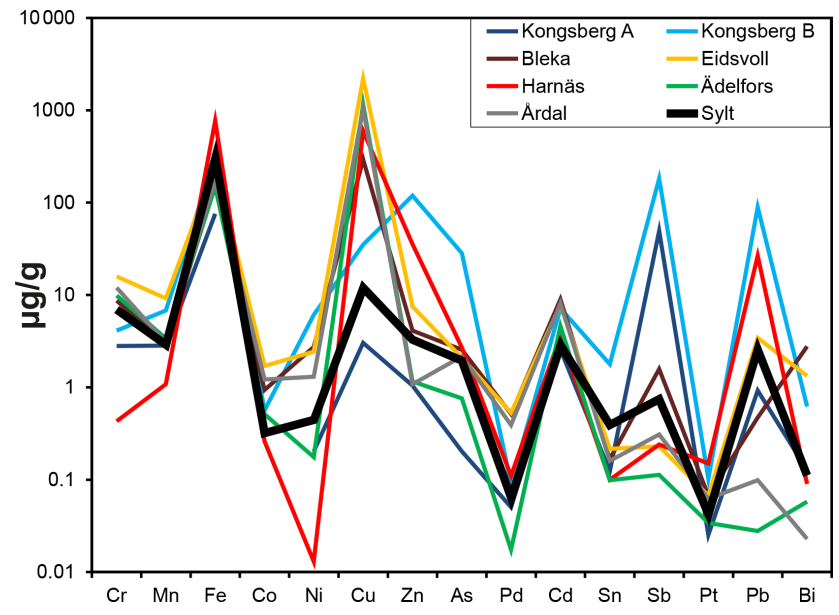

Figure 6. LA-ICP-MS analyses of southern Scandinavian gold and electrum samples (Tables 1 and 3) and the Sylt electrum find.

paratively rich in $\mathrm{Cu}$ and reveals higher levels of $\mathrm{Pd}$ and $\mathrm{Bi}$. The gold from Ädelfors is much richer in $\mathrm{Cu}$ compared to the electrum from Sylt but shows lower amounts of $\mathrm{Pd}, \mathrm{Sb}$, and $\mathrm{Pb}$. Gold from Ardal is richer in $\mathrm{Cu}$ and $\mathrm{Pd}$ but shows lower amounts of $\mathrm{Pb}$ and $\mathrm{Bi}$. The Harnäs gold sample has appreciably higher contents of $\mathrm{Cu}, \mathrm{Fe}, \mathrm{Zn}$, and $\mathrm{Pb}$ and a much lower $\mathrm{Ni}$ content than the Sylt electrum. The actual best fits for the trace element signatures are seen between the Sylt elec- 
Table 3. Trace elements (LA-ICP-MS; $\mu \mathrm{g} / \mathrm{g}$ ) of gold and electrum samples from Sylt, Kongsberg, and other southern Scandinavian gold occurrences ( $n=$ measuring points; Kongsberg A = quartz-calcite matrix; Kongsberg B = quartz matrix).

\begin{tabular}{lrrrrrrrrrrrrrrrr}
\hline & $\mathrm{Cr}$ & $\mathrm{Mn}$ & $\mathrm{Fe}$ & $\mathrm{Co}$ & $\mathrm{Ni}$ & $\mathrm{Cu}$ & $\mathrm{Zn}$ & $\mathrm{As}$ & $\mathrm{Pd}$ & $\mathrm{Cd}$ & $\mathrm{Sn}$ & $\mathrm{Sb}$ & $\mathrm{Pt}$ & $\mathrm{Pb}$ & $\mathrm{Bi}$ & $n$ \\
\hline Sylt, core & 6.97 & 2.90 & 305 & 0.32 & 0.45 & 12.0 & 3.29 & 1.95 & 0.06 & 2.86 & 0.39 & 0.74 & 0.04 & 2.58 & 0.11 & 16 \\
Sylt, rim & 25.9 & 30.6 & 267 & 5.32 & 0.70 & 8.82 & 2.67 & - & 0.04 & 11.6 & 12.6 & 2.39 & 0.02 & 4.75 & 1.34 & 7 \\
Årdal & 12.0 & 3.06 & 176 & 1.22 & 1.30 & 1045 & 1.08 & 2.16 & 0.39 & 8.15 & 0.16 & 0.31 & 0.06 & 0.10 & 0.02 & 5 \\
Ädelfors & 9.86 & 3.37 & 149 & 0.51 & 0.18 & 1157 & 1.16 & 0.76 & 0.02 & 4.61 & 0.10 & 0.11 & 0.03 & 0.03 & 0.06 & 8 \\
Bleka & 8.68 & 2.97 & 154 & 0.94 & 2.74 & 294 & 4.11 & 2.56 & 0.51 & 8.99 & 0.17 & 1.58 & 0.07 & 0.47 & 2.78 & 4 \\
Eidsvoll & 15.9 & 9.21 & 252 & 1.71 & 2.43 & 2208 & 7.49 & 2.08 & 0.53 & 7.80 & 0.22 & 0.23 & 0.07 & 3.44 & 1.33 & 5 \\
Harnäs & 0.43 & 1.08 & 769 & 0.26 & 0.013 & 597 & 35.5 & 2.69 & 0.11 & 3.61 & 0.10 & 0.24 & 0.15 & 36.6 & 0.09 & 6 \\
Falun & 8.35 & 3.14 & 147 & 0.39 & 0.18 & 563 & 1.13 & 0.25 & 0.02 & 5.61 & 0.15 & 0.51 & 0.04 & 0.08 & 0.07 & 13 \\
Ställdalen & 9.36 & 3.28 & 162 & 0.44 & 4.29 & 24.2 & 23.9 & 1.25 & 0.90 & 20.7 & 3.07 & 1.22 & 3.28 & 1.79 & 0.12 & 15 \\
Kongsberg A & 2.81 & 2.84 & 75.9 & - & 0.20 & 3.04 & 1.05 & 0.20 & 0.05 & 2.57 & 0.12 & 49.4 & 0.03 & 0.93 & 0.13 & 12 \\
Kongsberg B & 4.11 & 6.78 & 316 & 0.56 & 6.11 & 35.0 & 119 & 28.4 & 0.09 & 7.17 & 1.79 & 183 & 0.10 & 89.5 & 0.62 & 4 \\
\hline
\end{tabular}

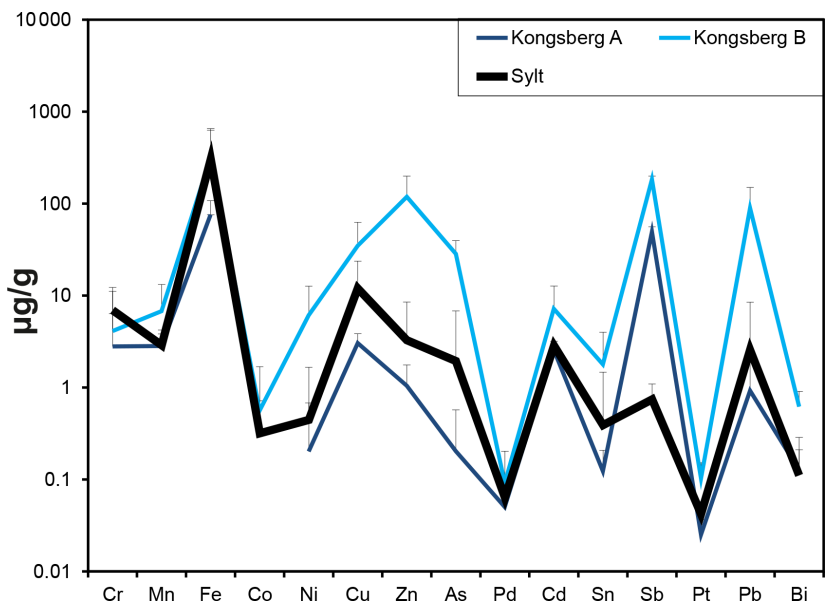

Figure 7. Comparison of LA-ICP-MS analyses (negative standard deviation omitted for reasons of clarity) of two Kongsberg electrum samples and the Sylt electrum find.

trum and the two Kongsberg electrum samples studied here (Fig. 7), in line with the similarity in their Au / Ag ratios.

This similarity between the Sylt and the Kongsberg samples is additionally evident by comparison of trace element ratios, e.g. $\mathrm{Pb} / \mathrm{Bi}$ vs. $\mathrm{Fe} / \mathrm{Cu}$ and $\mathrm{Cu} / \mathrm{Zn}$ vs. $\mathrm{Pd} / \mathrm{Pt}$ as illustrated in Fig. 8. These elements show a large variation in concentrations in Fig. 6 and thus may act as an additional fingerprint of the respective sample area. The Kongsberg and the Sylt samples group into a distinct cluster regarding these four element ratios: variable but high $\mathrm{Pb} / \mathrm{Bi}$ vs. high $\mathrm{Fe} / \mathrm{Cu}$ and variable but low $\mathrm{Cu} / \mathrm{Zn}$ vs. low $\mathrm{Pd} / \mathrm{Pt}$.

A classical cluster analysis on the trace elements of our samples considered above visualizes the chemical proximity between the Sylt find and the two Kongsberg samples (Fig. 9). Notwithstanding, both Kongsberg samples show a significant difference in the amount of $\mathrm{Sb}$ and also $\mathrm{Pb}$ in one case.

\subsection{Lead isotopes}

Gold and silver analyses and trace element profiles discussed above are still not sufficient to clearly define a single source of origin of the Sylt electrum. For this reason, we have also carried out $\mathrm{Pb}$ isotope analyses (Table 4) of the Sylt electrum find, an electrum sample from the Kongsberg deposit (Kongsberg A because its silver content and its trace element signature bear some similarities with the Sylt sample), and a gold sample from the Harnäs deposit because of its geographical proximity to the island of Sylt and its high Ag content in gold compared to other Scandinavian gold deposits.

Lead isotope data mainly from sulfide-rich deposits of the western part of the Baltic Shield are compiled by Romer and Wright (1993). These $\mathrm{Pb}$ isotope data from Svecofennian $(n=88)$ and Sveconorwegian $(n=10)$ sulfide deposits are shown in Fig. 10. The Pb isotope compositions of Sveconorwegian deposits are typically more radiogenic than those of comparable deposits of the Svecofennian province.

The $\mathrm{Pb}$ isotope data of the electrum from the Kongsberg mine and of the gold from the Harnäs deposit also correspond to the more radiogenic data of Sveconorwegian sulfide deposits. The position of our Sylt electrum sample in this diagram equally clearly points towards a Sveconorwegian provenance. While this is a good indicator towards Kongsberg as a potential source region, the radiogenic $\mathrm{Pb}$ isotope composition of the Sylt sample may alternatively also indicate (later) contamination or overprint by $\mathrm{Pb}$ derived from an older or generally more radiogenic source, especially if the gold matrix is low in $\mathrm{Pb}$ ab initio. This will be discussed below. As shown in Table 3, the $\mathrm{Pb}$ content of all investigated samples varies by up to 3 orders of magnitude (from $0.03 \mu \mathrm{g} / \mathrm{g}$ for Ädelfors to ca. $90 \mu \mathrm{g} / \mathrm{g}$ for Kongsberg), with the core of the Sylt electrum with $2.6 \mu \mathrm{g} / \mathrm{g} \mathrm{Pb}$ being only slightly above the median $(1.8 \mu \mathrm{g} / \mathrm{g} \mathrm{Pb})$. However, the rim of the Sylt sample contains more $\mathrm{Pb}(4.8 \mu \mathrm{g} / \mathrm{g})$ than the core. This can be interpreted as (i) contamination (in the laboratory, during glacial transport of the electrum and quartz 

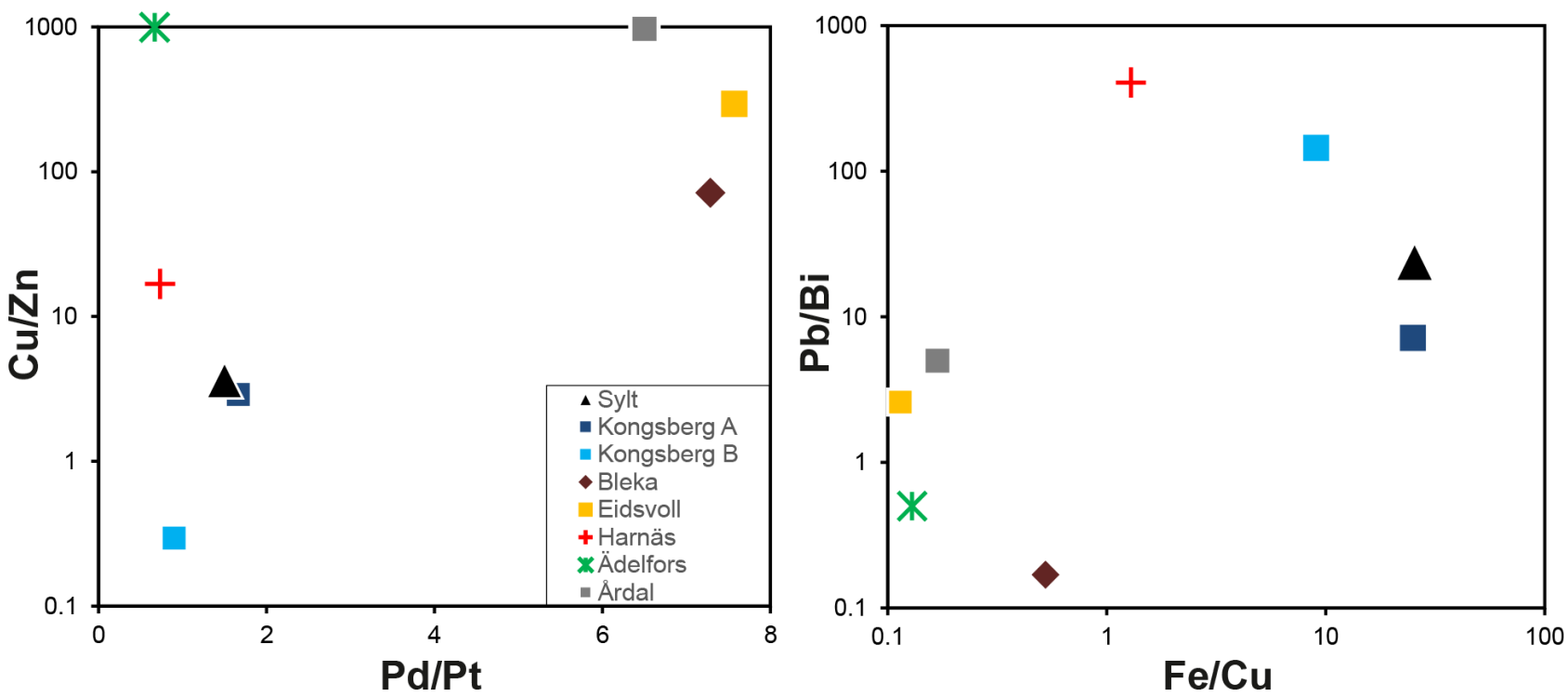

Figure 8. Element ratios of LA-ICP-MS analyses of southern Scandinavian gold and electrum samples (Tables 1 and 3) and the Sylt electrum find.

Table 4. $\mathrm{Pb}$ isotope data of the electrum samples from Sylt, Germany, and Kongsberg A, Norway, and a gold sample from Harnäs, Sweden.

\begin{tabular}{lrrrrrr}
\hline & ${ }^{206} \mathrm{~Pb} /{ }^{204} \mathrm{~Pb}$ & Internal error $^{\mathrm{a}}$ & ${ }^{207} \mathrm{~Pb} /{ }^{204} \mathrm{~Pb}$ & Internal error $^{\mathrm{a}}$ & ${ }^{208} \mathrm{~Pb} /{ }^{204} \mathrm{~Pb}$ & Internal error $^{\mathrm{a}}$ \\
\hline Sylt & 18.960 & 0.0283 & 15.671 & 0.0270 & 38.267 & 0.0281 \\
Sylt, leach & 19.283 & 0.0050 & 15.695 & 0.0058 & 38.785 & 0.0067 \\
Harnäs & 18.173 & 0.0266 & 15.558 & 0.0183 & 38.031 & 0.0215 \\
Harnäs, leach & 18.162 & 0.0057 & 15.561 & 0.0054 & 38.060 & 0.0067 \\
Kongsberg A & 19.592 & 0.0119 & 15.679 & 0.164 & 38.715 & 0.0222 \\
Kongsberg A, leach & 19.397 & 0.0065 & 15.675 & 0.0066 & 38.605 & 0.0082 \\
BIR-1, this study & 18.832 & 0.0067 & 15.661 & 0.0069 & 38.498 & 0.0074 \\
BIR-1 (GeoReM) ${ }^{b}$ & $18.834-18.889$ & & $15.634-15.674$ & & $38.449-38.542$ & \\
\hline
\end{tabular}

${ }^{\mathrm{a}}$ Internal error in $\% ;{ }^{\mathrm{b}}$ range given in the GeoReM database (http://georem.mpch-mainz.gwdg.de, last access: 12 July 2021).

pebble, or deposition in the till), (ii) post-mineralization overprint (e.g. by hydrothermal activity) before transport, or (iii) sample heterogeneity (primary, or secondary by transport). Contamination of the sample by anthropogenic $\mathrm{Pb}$ in the laboratory is highly unlikely given the excellent agreement of our data for the BIR-1 reference material (Table 4) and the low $\mathrm{Pb}$ blank of the $\mathrm{Pb}$ purification procedure (see Supplement).

Uptake of $\mathrm{Pb}$ during glacial transport and after deposition of the Sylt electrum within the till is a possible scenario, but it would require a fluid with abundant $\mathrm{Pb}$ coming into contact with the electrum for a sufficient duration. Neither the Scandinavian continental crust nor pre-industrial-revolution glacial ice is known to be enriched in $\mathrm{Pb}$ on a large scale. Today's topsoils in middle and southern Sweden and southern Norway have $\mathrm{Pb}$ concentrations typically close to the average upper continental crust with around $15 \mu \mathrm{g} / \mathrm{g}$, with local patches close to ore deposits and cities maybe exceeding $40 \mu \mathrm{g} / \mathrm{g}$ (Reimann et al., 2012). This exceeds the $\mathrm{Pb}$ content of the Sylt sample and many other samples investigated in this study. Yet the Sylt sample was found in a till without a recent soil cover because of constant erosion of the surface (Fig. 2). Thus, $\mathrm{Pb}$ contamination by fluids percolating the till and potentially mobilizing any $\mathrm{Pb}$ from the soil is unlikely given the low $\mathrm{Pb}$ concentration of $16 \mu \mathrm{g} / \mathrm{g}$ in soils existing elsewhere on Sylt today (i.e. similar to the $\mathrm{Pb}$ concentration in soils of southern Scandinavia; Reddy et al., 1982). Furthermore, $\mathrm{Pb}$ sorption behaviour in a loamy sand matrix is efficient (Fonseca et al., 2011), making postemplacement uptake of mobilized $\mathrm{Pb}$ by the electrum an unlikely scenario. The $\mathrm{Pb}$ concentration in the Greenland ice shield ca. 150000 years BP (i.e. close to the end of the Drenthe stage) was found to be $52 \pm 8 \mathrm{pg} / \mathrm{g}$ (Burton et al., 2007), i.e. several orders of magnitude lower than in the Sylt electrum, and glacial ice is thus also considered as an unlikely contributor of $\mathrm{Pb}$ to the Sylt sample during its transport by glacial masses. It is however worth noting that $\mathrm{Pb}$ may have been relatively enriched in the electrum's rim due to the se- 


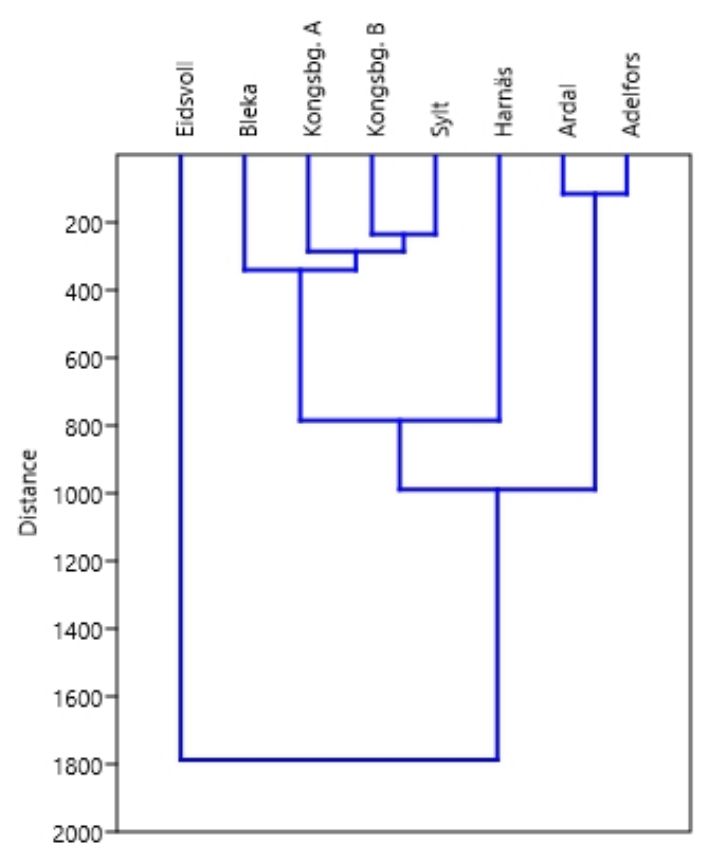

Figure 9. Cluster analysis of LA-ICP-MS data of southern Scandinavian gold and electrum samples (Tables 1 and 3) and the Sylt electrum find (hierarchical clustering, paired group algorithm, Euclidean similarity index).

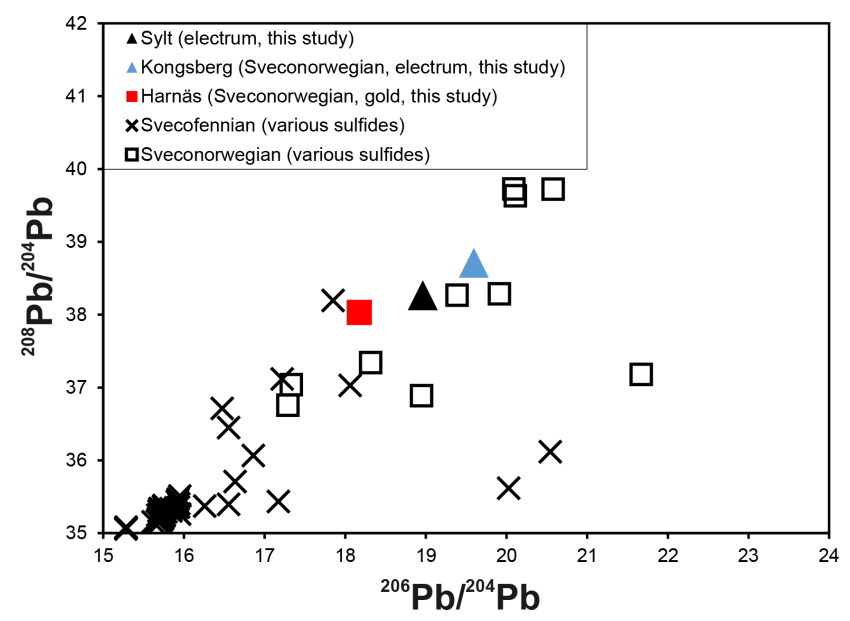

Figure 10. $\mathrm{Pb}$ isotopes from Scandinavian sulfide deposits (western part of the Baltic Shield; data from Romer and Wright, 1993), supplemented by $\mathrm{Pb}$ isotope data from the Sylt electrum, a Kongsberg electrum sample, and a Harnäs gold sample (this study).

vere loss of Ag during transport (see Table 2), with the latter being a well-known process for placer gold (e.g. Kerr et al., 2017; Stewart et al., 2017).

The incorporation of different amounts of $\mathrm{Pb}$ from isotopically different origins during the formation and/or transport of the electrum deposit cannot be entirely ruled out based on our $\mathrm{Pb}$ isotope data. In this context, it is however worth noting that the two Kongsberg samples differ by 2 orders of

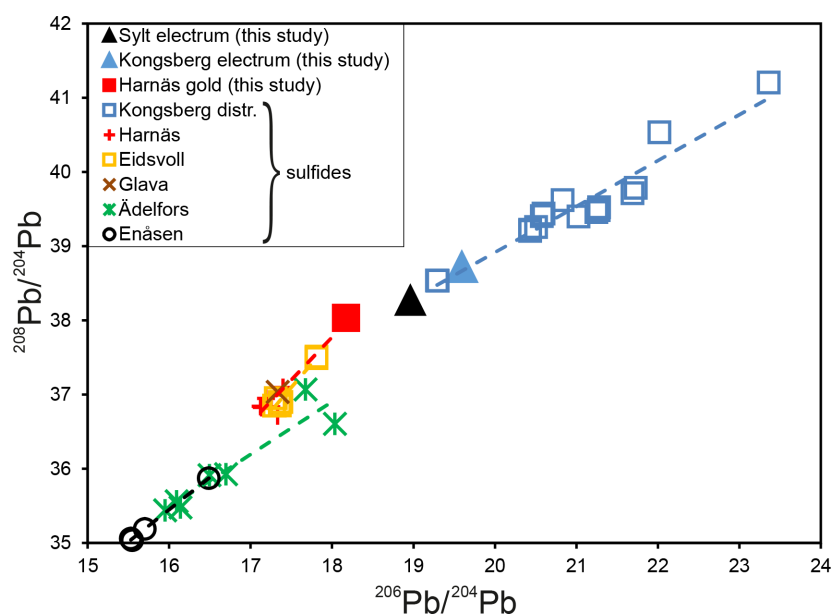

Figure 11. $\mathrm{Pb}$ isotope signatures of galena from southern Scandinavian gold occurrences and the mineralizations of the Kongsberg district. Data of Harnäs from Alm and Sundblad (1994), Ädelfors from Romer and Wright (1993), Eidsvoll from Sundblad and Ihlen (1995), Kongsberg from Bjørlykke et al. (1990), Enåsen from Hallberg (1989), and Glava from Romer and Wright (1993). Supplemented by $\mathrm{Pb}$ isotope data from the Sylt electrum, a Kongsberg electrum sample, and a Harnäs gold sample (this study). Analytical uncertainty is smaller than the symbol size.

magnitude in their $\mathrm{Pb}$ content (Table 3), suggesting a heterogeneous distribution of $\mathrm{Pb}$ (and other trace elements) already within this deposit. This heterogeneity is further illustrated in Fig. 11 by the large range of radiogenic $\mathrm{Pb}$ isotope compositions known for the Kongsberg deposit. A comparison of our $\mathrm{Pb}$ isotope data of electrum and gold (Sylt, Kongsberg, Harnäs) with $\mathrm{Pb}$ isotope signatures of galena from known gold occurrences or gold deposits published in the literature (Hallberg, 1989; Bjørlykke et al., 1990; Romer and Wright, 1993; Alm and Sundblad, 1994; Sundblad and Ihlen, 1995) reveals the following results. The most prominent Swedish gold deposit, Ädelfors, and the gold occurrences of Enåsen (both Svecofennian) have much less radiogenic $\mathrm{Pb}$ isotope signatures, thus ruling out an origin of the Sylt electrum from those deposits (Fig. 11). The Mjøsa-Vänern district located in the Sveconorwegian domain with its gold occurrences at Eidsvoll, Harnäs, and Glava has more radiogenic $\mathrm{Pb}$ isotope compositions, but these are still lower than those of the electrum from Sylt. The latter plots closer to samples of the Kongsberg district which reveal in general high radiogenic $\mathrm{Pb}$ isotope compositions (Fig. 11).

A mismatch between the Harnäs $\mathrm{Pb}$ isotope data from this study and the data published by Alm and Sundblad (1994) (Fig. 11) might be justified by the fact that the data of Alm and Sundblad (1994) and our data are based on different materials, galena and gold, respectively. As the $\mathrm{Pb}$ content of galena $(\mathrm{PbS})$ is several orders of magnitude higher than $\mathrm{U}$ because $\mathrm{U}$ is fitting poorly in the $\mathrm{PbS}$ crystal lattice (e.g. Hutta and Wright, 1964), radiogenic ingrowth of $\mathrm{Pb}$ due to $\mathrm{U}$ decay 
and thus a shift of the galena's $\mathrm{Pb}$ isotope composition with time can be considered negligible. Moreover, the high $\mathrm{Pb}$ content of galena makes it rather insensitive to a later modification of its $\mathrm{Pb}$ isotope signature by post-mineralization processes. For gold, uptake of $\mathrm{U}$ as a source of radiogenic $\mathrm{Pb}$ is supposed to be very low because (i) native $\mathrm{U}$ is not known on Earth and thus $\mathrm{Au}-\mathrm{U}$ alloys cannot form and (ii) $\mathrm{U}$ is mobile only in its oxidized form (e.g. as $\mathrm{U}^{\mathrm{VI}} \mathrm{O}_{2}^{2+}$ ) and thus will precipitate, for example, as uraninite $\left(\mathrm{UO}_{2}\right)$ at different conditions than those favourable for the formation of primary gold (which typically precipitates from saline hydrothermal or epithermal fluids). Consequently, the $\mathrm{Pb}$ isotope signature of placer (i.e. secondary) gold is dependent on $\mathrm{Pb}$ uptake during the formation and transport of the nugget (Kamenov et al., 2013). For the Sylt electrum sample however the $\mathrm{Pb}$ isotope signature of its core is most likely primary because of its very high Ag content - a feature that would have been lost during transport of the electrum and formation of placer gold (e.g. Kamenov et al., 2013; Kerr et al., 2017; Stewart et al., 2017). Notwithstanding the difference between galena and gold, the $\mathrm{Pb}$ isotope data of our Harnäs gold sample is still less radiogenic than the Sylt sample which shows a closer match with the Kongsberg samples. In addition to the different $\mathrm{Pb}$ isotope signatures, the deposits of Ädelfors, Harnäs, and Kongsberg define their own $\mathrm{Pb}$ isotope trends with different slopes in ${ }^{206} \mathrm{~Pb} /{ }^{204} \mathrm{~Pb}-{ }^{208} \mathrm{~Pb} /{ }^{204} \mathrm{~Pb}$ space as illustrated in Fig. 11. The electrum from Sylt overlaps the trend of the Kongsberg district mines.

Based on the previous observations, which point towards a Sveconorwegian provenance for the Sylt electrum and a probable relationship with the Kongsberg ore district, we took a closer look at mineralizations of the Oslo region.

Lead isotope data of galena compiled by Bjørlykke et al. (1990) from numerous ore deposits and ore occurrences in the Oslo Rift region are shown in Fig. 12. The PermoCarboniferous Oslo Paleo-rift comprises two half-grabens, named the Vestfold (VGS) and the Akershus graben (AGS) segments, which are filled with Permian sediments, volcanic and intrusive rocks, and Cambro-Silurian sediments (Bjørlykke et al., 1990). Different mineralizations occurred during the evolution of the Oslo Rift within the graben and along its margins. The metallogeny is dominated by the occurrence of hydrothermal ore deposits. Most of the ore deposits inside the Oslo Rift, the so called intra-magmatic deposits, are related to granitic intrusions with ages of ca. 270-265 Ma.

Numerous vein deposits furthermore occur within a 20 to $25 \mathrm{~km}$ wide aureole around the Oslo graben and are called rift-margin deposits (RMD). Their deposits and occurrences are situated in Precambrian gneisses and CambroSilurian sediments. The Kongsberg deposit belongs to the rift-margin deposits which do not show, different from the intra-magmatic deposits, any clear relation to granitic intrusions, but they often occur together with Permian dolerite dikes (Bjørlykke et al., 1990). The mineralizations within the two half-grabens (VGS and AGS; e.g. Drammen) are in

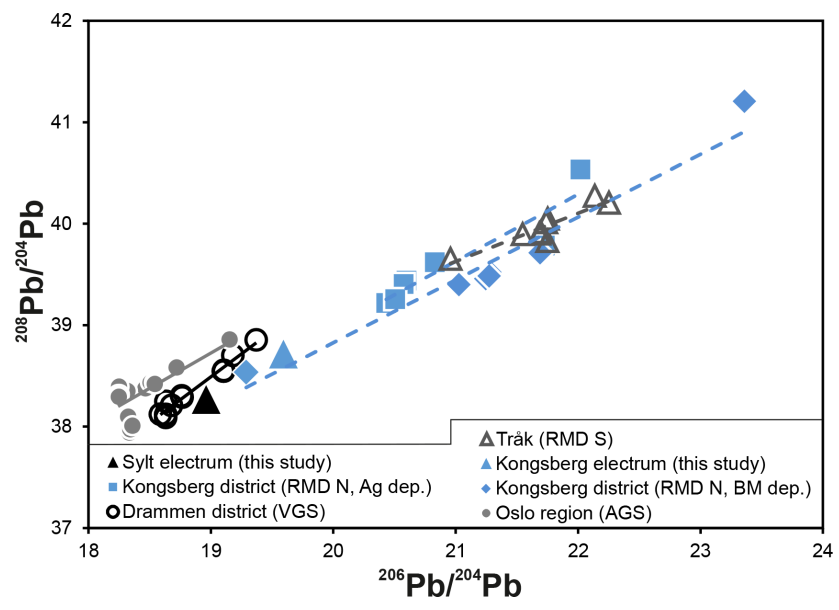

Figure 12. $\mathrm{Pb}$ isotope signatures of galena from ore deposits and ore occurrences of the Oslo Graben region (Bjørlykke et al., 1990). Pb isotope signatures of electrum form Sylt and Kongsberg (this study). AGS: Akershus graben segment (northern graben part); VGS: Vestfold graben segment (southern graben part); RMD: rift margin deposits (Kongsberg district, RMD N (north), and Tråk, RMD S (south); BM: base metals; dep.: deposit.

general less radiogenic than the mineralizations of the riftmargin deposits (Tråk and Kongsberg districts).

The Sylt electrum plots near the intra-magmatic deposits (e.g. Drammen). However, due to missing gold indicators in the ores of the intra-magmatic deposits like Drammen, a genetic link seems unlikely. On the other hand, the Sylt electrum sample and the Kongsberg electrum sample of our study are in line with the linear regression of Kongsberg silver deposits.

In summary, the Sylt electrum reveals

1. a silver content and a quartz matrix like the Kongsberg electrum samples

2. a trace element signature similar to the Kongsberg electrum samples when compared to all other reference samples

3. $\mathrm{Pb}$ isotope data consistent with a Sveconorwegian origin

4. $\mathrm{Pb}$ isotope data that show a higher similarity to the Kongsberg samples than to samples from gold deposits of the Mjøsa-Vänern district which also have their own distinct trace element signatures

5. $\mathrm{Pb}$ isotope data which suggest a genetic link with the silver deposits of the Kongsberg mining district.

Therefore, the assumption for a provenance of the Sylt electrum from southern Norway and probably from the Kongsberg mining district seems permissible. However, it still remains unclear if the source of the Sylt sample was an individual Kongsberg vein or even an independent rift-margin 
mineralization which is still undiscovered or was removed by the glaciers.

\section{Conclusions}

On the basis of the available samples and the data collected in this study, a clear determination of a distinct single known deposit as the origin of the Sylt electrum find is not $100 \%$ possible. However, several geochemical provenance proxies - which are the $\mathrm{Au} / \mathrm{Ag}$ ratio, trace element signatures, and $\mathrm{Pb}$ isotope compositions - seem to link the Sylt electrum find to southern Norway and most likely to the Kongsberg ore district or to an unknown mineralization in this region. Due to the small number of gold samples available for our study from each of the southern Scandinavian gold deposits, more investigation is necessary to discuss our hypothesis further.

A transportation of electrum from a mineralization in southern Norway to modern-day Sylt is consistent with our current state of knowledge on northern European glaciations.

The Sylt electrum clast might have been transported by glaciers from southern Norway to Sylt during the Saalian glaciation. Alternatively, it could have been transported to its Sylt location following two glaciations (Elsterian and Saalian), but that remains speculative.

Data availability. All data derived from this research are available upon request from the corresponding author.

Supplement. The supplement related to this article is available online at: https://doi.org/10.5194/ejm-33-373-2021-supplement.

Author contributions. JS and DW initiated the project. JS, StS, and ROCF performed the data collection and evaluation. JS and StS wrote the paper with input from ROCF. All authors discussed and interpreted the results.

Competing interests. The contact author has declared that neither they nor their co-authors have any competing interests.

Disclaimer. Publisher's note: Copernicus Publications remains neutral with regard to jurisdictional claims in published maps and institutional affiliations.

Acknowledgements. We like to thank the persons listed below which kindly supported and improved our study in many ways: Tonci Balic-Zunic (Copenhagen, Denmark), Matthias Bräunlich (Hamburg, Germany), Andreas Forsberg (Johanneshov, Sweden), Alf Grube (Hamburg, Germany), Stefanie Heidrich (Hamburg, Germany), Ingo Horn (Hannover, Germany), Erik Jonsson (Uppsala, Sweden), Niilo Kärkkäinen (Espoo, Finland), Kristin Ker- ber (Freiberg, Germany), Kåre Kullerud (Kongsberg, Norway), Hans-Jürgen Lierl (Trittau, Germany), Jörgen Langhof (Stockholm, Sweden), Karl-Christian Lyncker (Hamburg, Germany), Fred Steinar Nordrum (Kongsberg, Norway), Ralf-Dieter Schmitt (Berlin, Germany), Hans-Jürgen Stephan (Kiel, Germany), Peter Stutz (Hamburg, Germany), Krister Sundblad (Turku, Finland), Marc Theodor (Hamburg, Germany), Dan Topa (Vienna, Austria), Roland Vinx (Elmshorn, Germany), and Stefan Wiklund (Linköping, Sweden).

The manuscript benefitted from very constructive and helpful comments from Alain Plouffe and Krister Sundblad. Editorial handling by Reto Gieré and Vincent van Hinsberg is gratefully acknowledged.

Review statement. This paper was edited by Vincent van Hinsberg and reviewed by Alain Plouffe and Krister Sundblad.

\section{References}

Alm, E. and Sundblad, K.: Sveconorwegian polymetallic quartz veins in Sweden, Neues Jb. Miner. Monat., 1, 1-22, 1994.

Alm, E., Sundblad, K., Fallick, A. E., and Broman, C.: The Harnäs gold quartz veins, southwestern Sweden, in: Gold mineralization in the Nordic countries and Greenland, edited by: Ihlen, P. M., Pedersen, M., and Stendal, H., Grønlands Geologiske Undersøgelse, Open File Series, Copenhagen, 95/10, 6-7, 1995.

Alm, E., Broman, C., Billström, K., Sundblad, K., and Torssander, P.: Fluid characteristics and genesis of early Neoproterozoic orogenic gold-quartz veins in the Harnäs area, southwestern Sweden, Econ. Geol., 98, 1311-1328, 2003.

Bergman, T.: Mineralogisk-mineralkemisk undersökning av Ädelfors guldfyndighet, norra Småland, Examensarbete, Geologiska Institutionen, Stockholms Universitet, Maj 1986, 41 pp., 1986.

Bjørlykke, A., Ihlen, P. M., and Olerud, S.: Metallogeny and lead isotope data from the Oslo paleorift, Tectonophysics, 178, 109126, 1990.

Burton, G. R., Rosman, K. J. R., Candelone, J.-P., Burn, L. J., Boutron, C. F., and Hong, S.: The impact of climatic conditions on $\mathrm{Pb}$ and $\mathrm{Sr}$ isotopic ratios found in Greenland ice, 7-150 ky BP, Earth Planet. Sc. Lett., 259, 557-566, 2007.

Chapman, R., Mileham, T., Allan, M., and Mortensen, J.: A distinctive $\mathrm{Pd}-\mathrm{Hg}$ signature in detrital gold derived from alkalic $\mathrm{Cu}-\mathrm{Au}$ porphyry systems, Ore Geol. Rev., 83, 84-102, 2017.

Chapman, R. J. and Mortensen, J. K.: Characterization of gold mineralization in the northern Cariboo Gold District, British Columbia, Canada, through integration of compositional studies of lode and detrital gold with historical placer production: A template for evaluation of orogenic gold districts, Econ. Geol., 111, 1321-1345, 2016.

Chapman, R. J., Allan, M. M., Grimshaw, M. K., Mortensen, J. K., Wrighton, T. M., and Casselman, S.: Pathfinder signatures in placer gold derived from Au-bearing porphyries, in: Yukon exploration and geology 2013, edited by: MacFarlane, K. E., Nordling, M. G., and Sack, P. J., Yukon Geological Survey, Whitehorse, 21-31, 2014. 
Craw, D., Hesson, M., and Kerr, G.: Morphological evolution of gold nuggets in proximal sedimentary environments, southern New Zealand, Ore Geol. Rev., 80, 784-799, 2017.

Dietz, C. and Heck, H.-L.: Geologische Karte von Deutschland, 1 : 25000 - Erläuterungen zu den Blättern Sylt-Nord und Sylt-Süd, Landesanstalt für Angewandte Geologie, Kiel, 110 pp., 1952.

Ehlers, J., Grube, A., Stephan, H.-J., and Wansa, S.: Pleistocene glaciations of North Germany - New results, Dev. Quat. Sci., 15, 149-162, 2011.

Felix-Henningsen, P. and Urban, B.: Paleoclimatic interpretation of a thick intra-Saalian paleosol the "bleached loam" on the Drenthe moraines of northern Germany, Catena, 9, 1-8, 1982.

Fonseca, B., Figueriredo, H., Rodrigues, J., Queiroz, A., and Tavares, T.: Mobility of $\mathrm{Cr}, \mathrm{Pb}, \mathrm{Cd}, \mathrm{Cu}$ and $\mathrm{Zn}$ in a loamy sand soil: A comparative study, Geoderma, 164, 232-237, 2011.

Gaál, G. and Gorbatschev, R.: An outline of the Precambrian evolution in the Baltic Shield, Precambrian Res., 35, 15-52, 1987.

Hallberg, A.: Metal sources in the early Proterozoic Svecofennian terrain of central Sweden: $\mathrm{Pb}$ isotope evidence, Miner. Deposita, 24, 250-257, 1989.

Hallberg, A.: The Enåsen gold deposit, central Sweden. 1. A palaeoproterozoic high-sulphidation epithermal gold mineralization, Miner. Deposita, 29, 150-162, 1994.

Hallberg, A.: The Enåsen gold deposit, central Sweden - a Paleoproterozoic analogue to recent epithermal deposits, in: Gold mineralization in the Nordic countries and Greenland, edited by: Ihlen, P. M., Pedersen, M., and Stendal, H., Grønlands Geologiske Undersøgelse, Open File Series, Copenhagen, 95/10, 3941, 1995.

Hughes, P. D. and Gibbard, P. L.: Global glacier dynamics during 100 ka Pleistocene glacial cycles, Quat. Res., 90, 222-243, 2018.

Hutta, J. J. and Wright, H. D.: The incorporation of uranium and silver by hydrothermally synthesized galena, Econ. Geol., 59, 1003-1024, 1964.

Ihlen, P. M.: The geological evolution and metallogeny of the Oslo paleorift, in: Metallogeny associated with the Oslo paleorift, edited by: Olerud, S. and Ihlen, P. M., Sveriges Geologiska Undersökning, Ser. Ca, 59, 6-17, 1986a.

Ihlen, P. M.: The metallogeny of the Kongsberg district, in: Metallogeny associated with the Oslo paleorift, edited by: Olerud, S. and Ihlen, P. M., Sveriges Geologiska Undersökning, Ser. Ca, 59, 30-32, 1986b.

Ihlen, P. M.: Geology of gold deposits in the Eidsvoll - Odalen region, Norway, in: Gold mineralization in the Nordic countries and Greenland, edited by: Ihlen, P. M., Pedersen, M., and Stendal, H., Grønlands Geologiske Undersøgelse, Open File Series, Copenhagen, 95/10, 114-115, 1995.

Ihlen, P. M. and Nordrum, F. S.: The Kongsberg mining area a road log, in: Metallogeny associated with the Oslo paleorift, edited by: Olerud, S. and Ihlen, P. M., Sveriges Geologiska Undersökning, Ser. Ca, 59, 33-38, 1986.

Ihlen, P. M., Pedersen, M., and Stendal, H.: Gold mineralization in the Nordic countries and Greenland, Grønlands Geologiske Undersøgelse, Open File Series, Copenhagen, 95/10, 181 pp., 1995.

Kamenov, G. D., Melchiorre, E. B., Ricker, F. N., and DeWitt, E.: Insights from $\mathrm{Pb}$ isotopes for native gold formation during hypogene and supergene processes at Rich Hill, Arizona, Econ. Geol., 108, 1577-1589, 2013.
Kerr, G., Malloch, K., and Craw, D.: Diagenetic alteration of a Mesozoic fluvial gold placer deposit, southern New Zealand, Ore Geol. Rev., 83, 14-29, 2017.

Kullerud, K.: Elektrum i Kongsberg - bevis för en oupptäckt guldprovins?, Geologiskt Forum, 106, 16-19, 2020.

Lang, J., Lauer, T., and Winsemann, J.: New age constraints for the Saalian glaciation in northern central Europe: Implications for the extent of ice sheets and related proglacial lake systems, Quat. Sci. Rev., 180, 240-259, 2018.

Lierl, H.-J. and Jans, W.: Geschiebegold aus Schleswig-Holstein, Geschiebekunde aktuell, 6, 49-57, 1990.

Lierl, H.-J. and Sänger von Oepen, P.: Gibt es Gold in SchleswigHolstein?, Die Heimat - Zeitschrift für Natur- und Landeskunde von Schleswig-Holstein und Hamburg, 5, 147-152, 1993.

Lindström, M., Lundqvist, J., and Lundqvist, T.: Sveriges geologi från urtid till nutid, 2nd edn., Studentlitteratur, Lund, Sweden, 491 pp., 2000.

McInnes, M., Grennough, J. D., Freyer, B. J., and Wells, R.: Trace elements in native gold by solution ICP-MS and their use in mineral exploration: A British Columbia example, Appl. Geochem., 23, 1076-1085, 2008.

Oen, I. S. and Kieft, C.: Paragenetic relations of Bi-, Ag-, Au-, and other tellurides in bornite veins at Glava, Värmland, Sweden, Neues Jb. Miner. Abh., 149/3, 245-266, 1984.

Often, M.: Quaternary gold deposits in Norway, in: Gold mineralization in the Nordic countries and Greenland, edited by: Ihlen, P. M., Pedersen, M., and Stendal, H., Grønlands Geologiske Unders $\varnothing g e l s e$, Open File Series, Copenhagen, 95/10, 58-61, 1995.

Petersen, J. S. and Jensen, S. M.: Bleka gold fields in Telemark, South Norway, in: Gold mineralization in the Nordic countries and Greenland, edited by: Ihlen, P. M., Pedersen, M., and Stendal, H., Grønlands Geologiske Undersøgelse, Open File Series, Copenhagen, 95/10, 62-64, 1995.

Plouffe, A., Anderson, R. G., Gruenwald, W., Davis, W. J., Bednarski, J. M., and Paulen, R. C.: Integrating ice-flow history, geochronology, geology, and geophysics to trace mineralized glacial erratics to their bedrock source, an example from south central British Columbia, Can. J. Earth Sci., 48, 1113-1130, 2011.

Rea, M. A., Shuster, J., Hoffmann, V. E., Schade, M., Bissett, A., and Reith, F.: Does the primary deposit affect the biogeochemical transformation of placer gold and associated biofilms?, Gondwana Res., 73, 77-95, 2019.

Reddy, S. J., Valenta, P., and Nürnberg, H. W.: Simultaneous determination of the toxic trace metals $\mathrm{Cd}, \mathrm{Cu}, \mathrm{Pb}$ and $\mathrm{Zn}$ in soils by differential pulse anodic stripping voltammetry, Fresenius $\mathrm{Z}$. Anal. Chem., 313, 390-394, 1982.

Reimann, C., Flem, B., Fabian, K., Birke, M., Ladenberger, A., Négrel, P., Demetriades, A., and Hoogewerff, J.: The GEMAS Project Team. Lead and lead isotopes in agricultural soils of Europe - The continental perspective, Appl. Geochem., 27, 532$542,2012$.

Romer, R. L. and Wright, J. E.: Lead mobilization during tectonic reactivation of the western Baltic Shield, Geochim. Cosmochim. Ac., 57, 2555-2570, 1993.

Schade, M.: Gold- und Platinoid-Vorkommen in Deutschland, GOLD-Museum, Theuern, Germany, 499 pp., 2014.

Schuth, S., König, S., and Münker, C.: Subduction zone dynamics in the SW Pacific plate boundary region constrained from high- 
precision $\mathrm{Pb}$ isotope data, Earth Planet. Sc. Lett., 311, 328-338, 2011.

Stackebrandt, W., Ludwig, A. O., and Ostaficzuk, S.: Base of Quaternary deposits of the Baltic Sea depression and adjacent areas (map 2), Brandenburgische Geowissenschaftliche Beiträge, 8, 13-19, 2001.

Stea, R. R. and Pe-Piper, G.: Using whole rock geochemistry to locate the source of igneous erratics from drumlins on the Atlantic coast of Nova Scotia, Boreas, 28, 308-325, 1999.

Stephan, H.-J.: Zur Entstehung der eiszeitlichen Landschaft Schleswig-Holsteins, Schriften des Naturwissenschaftlichen Vereins für Schleswig-Holstein, 67, 101-118, 2003.

Stephan, H.-J.: Fließrichtungen eiszeitlicher Gletscher in Schleswig-Holstein, Schriften des Naturwissenschaftlichen Vereins für Schleswig-Holstein, 75, 48-82, 2020.
Stewart, J., Kerr, G., Prior, D., Halfpenny, A., Pearce, M., Hough, R., and Craw, D.: Low temperature recrystallisation of alluvial gold in paleoplacer deposits, Ore Geol. Rev., 88, 43-56, 2017.

Sundblad, K.: Metallogeny of gold in the Precambrian of northern Europe, Econ. Geol., 98, 1271-1290, 2003.

Sundblad, K. and Ihlen, P. M.: Gold mineralization in Fennoscandia: An overview, in: Gold mineralization in the Nordic countries and Greenland, edited by: Ihlen, P. M., Pedersen, M., and Stendal, H., Grønlands Geologiske Undersøgelse, Open File Series, Copenhagen, 95/10, 114-148, 1995.

Trusheim, F.: Mechanism of salt migration in northern Germany, Bull. Am. Assoc. Petrol. Geol., 44, 1519-1540, 1960. 